\title{
EFEKTIFITAS MODEL DISCOVERY LEARNING DAN GUIDED DISCOVERY DITINJAU DARI KETRAMPILAN PEMECAHAN MASALAH MATEMATIKA TERHADAP HASIL BELAJAR
}

\author{
Putri Oktaviana Zunita ${ }^{1}$, Henny Dewi ${ }^{2}$, Sri Giarti ${ }^{3}$ \\ 1,2,3 Jurusan Pendidikan Guru Sekolah Dasar, FKIP \\ Universitas Kristen Satya Wacana \\ Salatiga, Indonesia \\ email : 292014110@student.uksw.edu', henny.dewi@staff.uksw.edu², \\ sgiarty@gmail.com ${ }^{3}$
}

\begin{abstract}
Abstrak
Penelitian ini adalah penelitian eksperimen. Tujuan penelitian untuk meningkatkan ketrampilan pemecahan masalah dan hasil belajar matematika kelas 4 SD Dabin 2 dan 3 kecamatan GodongGrobogan menggunakan model pembelajaran Discovery Learning dan Guided Discovery. Sampel penelitian ini adalah kelas 4 SD Dabin 2 yang berjumlah 55 dan Dabin 3 berjumlah 62 . Dalam hasil analisa dua tahap, yaitu tahap awal menggunakan nilai pretest dan analisa tahap akhir menggunakan nilai postest. Tahap awal dan akhir dihitung menggunakan uji normalitas, uji homogenitas, uji homogenitas koefisien regresi linear, dan uji ANCOVA. Berdasarkan uji ANCOVA TWO WAYS yang telah dilakukan terhadap nilai pretest dan posttest kelompok eksperimen 1 dan kelompok eksperimen 2 diperoleh hasil signifikansi/probabilitas 0,870 dan 0,395 atau > 0,05 maka $\mathrm{HO}$ diterima dan $\mathrm{Ha}$ ditolak. Artinya tidak terdapat perbedaan ketrampilan pemecahan masalah dan hasil belajar matematika yang signifikan dalam menggunakan model pembelajaran Discovery Learning dan Guided Discovery pada siswa kelas 4 SD Dabin 2 dan Dabin 3 kecamatan Godong-Grobogan.
\end{abstract}

Kata Kunci : Discovery Learning dan Guided Discovery, Ketrampilan Pemecahan Masalah dan Hasil Belajar Matematika.

\begin{abstract}
This research is experimental research. The purpose of the research is to improve problem solving skills and learning outcomes of 4th grade elementary school Dabin 2 and 3 Godong-Grobogan subdistricts using learning model of Discovery Learning and Guided Discovery. The sample of this research is grade 4 SD Dabin 2 which amounts to 55 and Dabin 3 amounted to 62. In the result of two stage analysis, that is initial stage using pretest value and final stage analysis using postest value. The initial and final stages are calculated using normality test, homogeneity test, homogeneity test of linear regression coefficient, and ANCOVA test. Based on ANCOVA TWO WAYS test that has been done to pretest and posttest value of experimental group 1 and experiment group 2 obtained result of significance / probability 0,870 and 0,395 or $>0,05$ then $\mathrm{HO}$ accepted and Ha rejected. This means that there is no difference in problem solving skills and significant mathematics learning outcomes in using the learning model of Discovery Learning and Guided Discovery in 4th grade students of Dabin 2 and Dabin 3 districts of Godong-Grobogan.
\end{abstract}

Keywords: Discovery Learning and Guided Discovery, Problem Solving Skills and Mathematics Learning Outcomes 


\section{Pendahuluan}

Menurut Departemen Pendidikan Nasional No. 20 tahun 2003 menjelaskan bahwa matematika adalah suatu bahan kajian yang memiliki objek abstrak dan dibangun melalui proses penalaran deduktif, yaitu kebenaran suatu konsep diperoleh sebagai akibat logis dari kebenaran sebelumnya sehingga keterkaitan antar konsep dalam matematika bersifat sangat kuat dan jelas. Lebih lanjut pembelajaran matematika ditinjau dari fungsi dan tujuan menurut Departemen Pendidikan Nasional No. 20 tahun 2003 matematika berfungsi untuk mengembangkan kemampuan bernalar melalui kegiatan penyelidikan, eksplorasi, dan eksperimen, sebagai alat pemecahan masalah melalui pola pikir dan model matematika, serta sebagai alat komunikasi melalui simbol, tabel, grafik, diagram, dalam menjelaskan masalah. Sedangkan tujuan matematika yaitu melatih dan menumbuhkan cara berfikir secara sistematis, logis, kritis, kreatif, dan konsisten serta mengembangkan sikap gigih dan percaya diri sesuai dalam menyelesaikan masalah. Selanjutnya, Permendiknas Nomor 22 Tahun 2006 tentang Standar Isi mengatakan bahwa matematika merupakan ilmu yang menjadi pondasi perkembangan teknologi modern dan mempunyai peran penting dalam memajukan daya pikir manusia.

Menurut Daryanto (2012: 240) matematika merupakan pembelajaran yang menekankan kepada siswa untuk berfikir secara logis, sistematis, kritis, dan bekerja sama sehingga mampu mengembangkan kemampuan dalam memecahkan berbagai masalah sehari-hari. Sejalan dengan pendapat Daryanto, Uno (2008:129) juga mengemukakan bahwa matematika merupakan suatu bidang ilmu yang menjadi alat pikir, berkomunikasi, dan alat untuk memecahkan berbagai masalah atau persoalan yang praktis, unsur-unsurnya adalah logika dan intuisi, analitis, dan kontruksi, generalitas, dan individualis. Sedangkan menurut Muhsetyo (2008:26) menyatakan bahwa pembelajaran matematika adalah proses pemberian pengalaman belajar kepada peserta didik melalui serangkaian kegiatan yang terencana sehingga peserta didik memperoleh kompetensi tentang bahan matematika yang dipelajari.

Johnson dan Rising seperti yang dikutip dalam Erman Suherman (2001: 19) menyatakan bahwa matematika adalah pola berpikir, pola mengorganisasikan, pembuktian yang logik. Matematika itu adalah bahasa yang menggunakan istilah yang didefinisikan dengan cermat, jelas, dan akurat, representasinya dengan simbol dan padat, lebih berupa bahasa simbol mengenai ide dari pada mengenal bunyi. Selanjutnya menurut Karso (2007: 1.4) menyatakan bahwa "matematika adalah ilmu yang deduktif, aksiomatik, formal, hirarkis, abstrak, bahasa simbol yang padat arti dan semacamnya".

Pernyataan diatas menandakan bahwa matematika adalah ilmu yang deduktif, aksiomatik, formal, hirarki, abstrak dan juga suatu bidang ilmu yang menjadi alat pikir, berkomunikasi, alat untuk berfikir secara logis, sistematis, kritis, dan bekerja sama sehingga mampu mengembangkan kemampuan dalam memecahkan berbagai masalah.

Tujuan mata pelajaran matematika menurut Permendiknas nomor 22 tahun 2006 adalah sebagai berikut: (a) Memahami konsep matematika, (b) Menggunakan penalaran pada pola dan sifat, (c) Memecahkan masalah yang meliputi kemampuan memahami masalah, (d) Mengomunikasikan gagasan dengan simbol, tabel, diagram, atau media lain, (e) Memiliki sikap menghargai kegunaan matematika dalam kehidupan.

Model pembelajaran sangat berpengaruh dalam menunjang keberhasilan proses belajar mengajar. Ada banyak model pembelajaran yang dikemukan oleh Slameto (2011: 7) menyebutkan model pembelajaran inovatif, diantaranya; Cooperative Learning, Contextual 
Teaching and Learning, Realistik Mathematics Education, Problem Based Learning, Problem Promting, Cycle Learning, Example and Non Example dari berbagai model pembelajaran diatas maka model pembelajaran yang sesuai dengan pembelajaran matematika adalah model Discovery learning dan Guided Discovery karena model ini yang cocok untuk di uji cobakan pada pembelajaran pemecahan masalah matematika dan hasil belajar. Hosnan (2014: 282) menjelaskan bahwa Discovery Learning adalah suatu model untuk mengembangkan cara belajar aktif dengan menemukan sendiri, menyelidiki sendiri, maka hasil yang diperoleh akan setia dan tahan lama dalam ingatan. Selanjutnya menurut Jamil Suprihatiningrum (2014: 241) mengatakan bahwa dalam model Discovery Learning,siswa didorong untuk belajar aktif melalui keterlibatan aktif mereka sendiri dengan konsep-konsep, prinsip-prinsip, dan guru mendorong siswa untuk memiliki pengalaman dan melakukan percobaan yang memungkinkan mereka menemukan prinsip-prinsip untuk diri mereka sendiri.

Adapun langkah-langkah yang dikemukakan oleh Agus N. Cahyo (2013: 123) langkahlangkah dalam pendekatan discovery learning adalah sebagai berikut: (1) Stimulation, (2) Problem statement, (3) Data collection, (4) Data processing, (5) Verification, (6) Generalization. Selanjutnya Kemendikbud (2014) menjelaskan kelebihan model Discovery Learning diantaranya: a) Membantu siswa untuk memperbaiki dan meningkatkan keterampilan- keterampilan dan proses-proses kognitif; b) Menimbulkan rasa senang pada siswa, karena tumbuhnya rasa menyelidiki dan berhasil; c) Menyebabkan siswa mengarahkan kegiatan belajarnya sendiri dengan melibatkan akalnya dan motivasi sendiri; d) Membantu siswa memperkuat konsep dirinya, karena memperoleh kepercayaan bekerja samadengan yang lainnya; e) Berpusat pada siswa dan guru berperan sama- sama aktif mengeluarkan gagasan-gagasan; f) Membantu siswa menghilangkan skeptisme (keraguraguan) karena mengarah pada kebenaran yang final dan tertentu atau pasti.

Model pembelajaran ketrampilan pemecahan masalah matematika yang selanjutnya menurut Eggen dan Kauchak (2009:222) mengatakan bahwa Guided Discovery adalah suatu metode pembelajaran yang disusun untuk menjelaskan konsep-konsep dan hubungan antar konsep dengan jelas sehingga dapat menciptakan pembelajaran yang terarah dan sistematis. Sedangkan menurut Mardiati (2017: 18) Model pembelajaran Guided Discovery yaitu model pembelajaran yang menitik beratkan pada aktifitas peserta didik dalam belajar, guru hanya bertindak sebagai pembimbing dan fasilitator yang mengarahkan peserta didik untuk menemukan sendiri konsep, definisi, prosedur, algoritma dan sebagainya. Menurut Suhana (2014: 44) megatakan bahwa Guided Discovery yaitu pelaksanaan penemuan dilakukan atas petunjuk dari guru, pembelajarannya dimulai dari guru mengajukan pertanyaan yang melacak dengan tujuan untuk mengarahkan peserta didik kepada titik kesimpulan kemudian siswa melakukan percobaan untuk membuktikan pendapat yang dikemukakan.

Pernyataan di atas menandakan bahwa model pembelajaran Guided Discovery adalah pembelajaran yang menjelaskan tentang konsep-konsep dan hubungan antar konsep dengan jelas, sehingga dapat menciptakan pembelajaran yang terarah dan sistematis, pembelajaran Guided Discovery juga memusatkan siswa untuk belajar aktif dan siswa juga dapat memahami benar bahan pelajaran, sebab siswa mengalami sendiri proses menemukannya dan siswa juga dapat merasakan kepuasan dalam memecahkan masalah.

Mardiati (2017: 20) menyebutkan langkah-langkah model pembelajaran Guided Discovery adalah sebagai berikut: (1) Fase Orientasi, (2) Fase Hypothesis Generation, 3) Fase Hypothesis Testing, (4) Fase Cunclution, (5) Fase Regulation. 
Banyak keraguan tentang model Discovery Learning dan Guided Discovery dalam meningkatkan ketrampilan pemecahan masalah dan hasil belajar matematika, oleh karena itu dalam penelitian ini akan membuktikan keefektifan model Discovery Learning dan Guided Discovery bahwa pembelajaran yang dilakukan dengan kedua model dapat meningkatkan keefektifan ketrampilan pemecahan masalah matematika dan hasil belajar siswa. Dari berbagai model pembelajaran itu maka penulis tertarik untuk melakukan penelitian tentang keampuhan model Discovery Learning Dan Guided Discovery karena berdasarkan hasil penelitian apakah terdapat perbedaan antar model Discovery Learning Dan Guided Discovery.

\section{Metode}

Jenis penelitian yang digunakan adalah penelitian eksperimental jenis Quasi Experimental atau eksperimen semu. Menurut Sugiyono (2006: 87), metode eksperimen semu merupakan pengembangan dari true experimental design yang sulit dilaksanakan. Desain ini mempunyai variabel kontrol tetapi tidak digunakan sepenuhnya untuk mengontrol variabel luar yang mempengaruhi pelaksanaan eksperimen. Desain ini digunakan jika peneliti dapat melakukan kontrol atas berbagai variabel yang berpengaruh, tetapi tidak cukup untuk melakukan eksperimen yang sesungguhnya.

Desain yang digunakan dalam penelitian ini adalah Non-equivalent Control Group Design. Sugiyono (2013:116) mengemukakan bahwa Non-equivalent Control Group Design hamper sama dengan Pretest-posttest Control Group Design, hanya pada desain ini kelas eksperimen 1 maupun eksperimen 2 tidak dipilih secara random. Pemilihan kelompok eksperimen dilakukan secara matching only lebih memungkinkan untuk dilakukan dibandingkan pemilihan secara random; karena dalam merandom subjek penelitian dibutuhkan izin dari setiap kepala sekolah agar beberapa siswa yang ditunjuk dapat menjadi subjek penelitian. Kedua kelompok tersebut (kelompok eksperimen 1 dan eksperimen 2) diberikan pretest dan posttest untuk mengetahui adanya perbedaan yang signifikan antara kelompok eksperimen 1 dan eksperimen 2 (Sugiyono, 2014:116).

Sampel adalah bagian dari populasi. Sampel adalah sebagian dari jumlah dan karakteristik yang dimiliki oleh populasi tersebut, ataupun bagian kecil dari anggota populasi yang diambil menurut prosedur tertentu sehingga dapat mewakili populasinya Suharsimi Arikunto (2009:11). Penggunaan sampel dilakukan dengan pertimbangan bahwa tidak mungkin dilakukan penelitian dengan populasi yang besar. Apa yang dipelajari dari sampel, kesimpulannya dapat diberlakukan untuk populasi, dengan syarat sampel yang diambil harus representative atau mewakili (Sugiyono, 2015: 62). Agar didapatkan sampel yang representative, maka diperlukan teknik pengambilan sampel.

Dalam penelitian ini, peneliti menggunakan teknik purposif sampling. Purposif sampling atau berdasarkan tujuan yang pengambilan sampelnya di sesuaikan dengan tujuan penelitian.Dalam penelitian ini, sampel yang digunakan yaitu siswa kelas IV SD Negeri Klampok 01, SD Negeri Klampok 02, SD Negeri Kopek, SD Negeri Kemloko 02 kecamatan Godong-Grobogan.

Analisis data pada penelitian ini menggunakan teknik analisis statistik dan deskriptif kualitatif. Analisis statistik yang dilakukan dalam penelitian ini dilaksanakan dengan bantuan SPSS 20.0 for windows. Adapun analisis deskriptif kualitatif dipergunakan untuk menganalisis data dan informasi dari hasil pengamatan dan hasil dari interprestasi analisis statistik dengan SPSS. 
Sebelum melakukan analisis data, terlebih dahulu dilaksanakan uji prasyarat analisis, yaitu uji normalitas, uji homogenitas, uji homogenitas koefisien regresi linier, dan uji ANCOVA. Hipotesis yang akan diuji dalam penelitian eksperimen ini adalah:

1. Ho : $\mu 1=\mu 2$ artinya tidak terdapat perbedaan ketrampilan pemecahan masalah dan hasil belajar matematika yang signifikan pada siswa kelas 4 dabin 2 dan dabin 3 dalam pembelajaran menggunakan model Discovery Learning dan Guided Discovery.

2. Ha : $\mu 1 \neq \mu 2$ artinya terdapat perbedaan ketrampilan pemecahan masalah dan hasil belajar matematika yang signifikan pada siswa kelas 4 dabin 2 dan dabin 3 dalam pembelajaran menggunakan model Discovery Learning dan Guided Discovery.

\section{Hasil Penelitian}

Penelitian ini bertujuan untuk mengetahui perbedaan hasil belajar yang signifikan dalam penerapan model pembelajaran model Discovery Learning dan Guided Discovery pada mata pelajaran matematika kelas 4 SD Dabin 2 dan Dabin 3.Hasil uji hipotesis menggunakan teknik ANCOVA TWO WAYS seperti telah dilakukan terhadap nilai pretest dan posttest kelompok eksperimen 1 dan kelompok eksperimen 2 diperoleh hasil signifikansi/probabilitas 0,870 dan 0,395 atau > 0,05 maka $\mathrm{HO}$ diterima dan Ha ditolak. Artinya tidak terdapat perbedaan dalam ketrampilan pemecahan masalah dan hasil belajar matematika yang signifikan pada siswa kelas 4 SD Dabin 2 dan Dabin 3 dalam pembelajaran menggunakan model pembelajaran Discovery Learning dan Guided Discovery. Deskripsi tersebut disajikan dalam bentuk tabel dan grafik sebagai berikut.

Tabel 1. Tabel Komparasi Hasil Pengukuran Kelompok Eksperimen 1 dan Kelompok Eksperimen 2

\begin{tabular}{cccc}
\hline Tahap Pengukuran & \multicolumn{2}{c}{ Rerata Skor (mean) kelompok } & Keterangan Selisih \\
& Eksperimen 1 & Eksperimen 2 & \\
\hline Pretest & 58,45 & 68,52 & 10,07 \\
Posttest & 70,54 & 77,41 & 6,87 \\
\hline
\end{tabular}

Berdasarkan tabel 1 di atas, dapat diketahui adanya perbedaan skor rata-rata tahap pengukuran pretest dan posttest kelompok eksperimen1 dan kelompok eksperimen 2. Perbedaan skor rata-rata tersebut ditunjukkan oleh adanya selisih skor rata-rata antara kelompok eksperimen1 dan kelompok eksperimen 2. Pada tahap pengukuran pretest terdapat perbedaan skor rata-rata yang ditunjukkan oleh adanya selisih skor antar kelompok eksperimen 1 dan kelompok eksperimen 2 sebesar 10,07. Padatahap pengukuran pretest, 10,07 rata rata kolompok eksperimen 1 lebih rendah dibandingkan skor rata-rata kelompok eksperimen 2. Sedangkan pada tahap pengukuran posttest terdapat perbedaan skor ratarata kelompok eksperimen 1 dan kelompok eksperimen 2 sebesar 6,87. Pada tahap pengukuran posttest, skor rata-rata kelompok eksperimen 1 lebih rendah dibandingkan skor rata-rata kelompok eksperimen 2.

Hasil uji perbedaan rerata meningkatkan ketrampilan pemecahan masalah dan hasil belajar kelompok eksperimen 1 dan kelompok eksperimen 2 serta teknik analisis data menggunakan teknik analisis statistik dan deskriptif kualitatif. Analisis statistik yang dilakukan dalam penelitian ini dilaksanakan dengan bantuan SPSS 20.0 for windows. Adapun analisis deskriptif kualitatif dipergunakan untuk menganalisis data dan informasi dari hasil 
pengamatan dan hasil dari interprestasi analisis statistik dengan SPSS. Sebelum melakukan analisis data, terlebih dahulu dilaksanakan uji prasyarat analisis, yaitu uji normalitas, uji homogenitas, uji homogenitas koefisien regresi linier, dan uji ANCOVA.

Uji normalitas data dapat diketahui dengan menggunakan data berdistribusi normal atau tidak. Salah satu uji normalitas yang digunakan adalah One Sample Kolmogorov Smirnov. Untuk pengambilan keputusan uji normalitas yakni jika nilai signifikansi $>0,05$ maka data tersebut berdistribusi normal. Jika nilai signifikan $<0,05$ maka data tersebut tidak berdistribusi normal. Uji normalitas data pretest dan posttest pada kelompok eksperimen 1 dan eksperimen 2 dapat dilakukan menggunakan SPSS 20.0 for Windows.

Tabel 2. Hasil Uji Normalitas pretest dan postest ketrampilan pemecahan masalah dan hasil belajar matematika pada kelompok eksperimen 1 dan kelompok eksperimen 2

One-Sample Kolmogorov-Smirnov Test

\begin{tabular}{|c|c|c|c|c|c|}
\hline & & $\begin{array}{l}\text { pretest_eksp } \\
\text { erimen1 }\end{array}$ & $\begin{array}{c}\text { postest_eksp } \\
\text { erimen1 }\end{array}$ & $\begin{array}{l}\text { pretest_eksp } \\
\text { erimen2 }\end{array}$ & $\begin{array}{c}\text { postest_eksp } \\
\text { erimen2 }\end{array}$ \\
\hline \multicolumn{2}{|c|}{$\mathrm{N}$} & 55 & 55 & 62 & 62 \\
\hline \multirow{2}{*}{$\begin{array}{l}\text { Normal } \\
\text { Parameters } \\
\text { a,b }\end{array}$} & Mean & 58,4545 & 70,5455 & 67,8226 & 77,4194 \\
\hline & Std. Deviation & 16,43936 & 16,62976 & 16,46210 & 16,48999 \\
\hline \multirow{3}{*}{$\begin{array}{l}\text { Most } \\
\text { Extreme } \\
\text { Differences }\end{array}$} & Absolute & ,119 & ,178 & ,093 & ,113 \\
\hline & Positive & , 106 & , 138 & , 070 & ,085 \\
\hline & Negative &,- 119 &,- 178 &,- 093 &,- 113 \\
\hline \multicolumn{2}{|c|}{ Kolmogorov-Smirnov Z } & ,885 & 1,319 & ,731 & ,887 \\
\hline \multicolumn{2}{|c|}{ Asymp. Sig. (2-tailed) } & 414 & ,062 & 659 & 411 \\
\hline
\end{tabular}

Berdasarkan tabel 2 di atas dapat dilihat bahwa nilai Asymp. Sig. (2-tailed) uji Kolmogorov-Smirnov $Z$ hasil pretest-posttest kelompok eksperimen 1adalah 0,414 dan 0,62. Sedangkan hasil pretest-posttest kelompok eksperimen 2 adalah 0,659 dan 0,411. Bila dirumuskan sebuah hipotesis $\mathrm{HO}$ adalah sebuah sampel yang berasal dari populasi berdistribusi normal dan $\mathrm{Ha}$ adalah sampel yang tidak berasal dari populasi berdistribusi normal, maka dapat diputuskan jika probabilitas < nilai $\alpha(0,05) \mathrm{H} 0$ ditolak, jika sebaliknya maka $\mathrm{HO}$ diterima. Oleh karena nilai signifikansi/probabilitas Asymp. Sig. (2-tailed) data-data tersebut berturut-turut 0,$414 ; 0,62 ; 0,659$ dan $0,411>0,05$ maka $\mathrm{H} 0$ diterima, artinya dapat disimpulkan bahwa persebaran data hasil pretest-posttest kelompok eksperimen 1 dan kelompok eksperimen 2 tersebut berasal dari populasi yang berdistribusi normal.

Setelah uji normalitas terpenuhi, selanjutnya akan dilakukan uji coba homogenitas untuk mengetahui kedua varian homogen atau tidak. Uji ini dilakukan sebagai syarat dalam analisis Ancova. Uji homogenitas dalam penelitian ini menggunakan uji Ancova, kriterianya varian data kedua kelompok dikatakan homogen jika nilai signifikansi $>0,05$ dan jika nilai signifikan $<0,05$ maka data dikatakan tidak homogen. Analisis uji homogenitas varian ini dilakukan menggunakan software spss 20.0 for windows. 
Tabel 3. Hasil Uji Homogenitas Pretest Ketrampilan Pemecahan Masalah dan Hasil Belajar pada Kelompok Eksperimen 1 dan Eksperimen 2

Test of Homogeneity of Variance

\begin{tabular}{llrrrr}
\hline & & $\begin{array}{c}\text { Levene } \\
\text { Statistic }\end{array}$ & df1 & df2 & Sig. \\
\hline data_pretest & Based on Mean &, 091 & 1 & 115 &, 763 \\
& Based on Median &, 051 & 1 & 115 &, 822 \\
& $\begin{array}{l}\text { Based on Median and } \\
\text { with adjusted df }\end{array}$ &, 051 & 1 & 114,954 &, 822 \\
& & & & & \\
& $\begin{array}{l}\text { Based on trimmed } \\
\text { mean }\end{array}$ &, 120 & 1 & &, 729 \\
\hline
\end{tabular}

Berdasarkan tabel 3 diatas dapat diketahui bahwa Test of Homogeneity of Variance pada Based on Mean menunjukan nilai signifikan sebesar $0,763(0,763>0,05)$, pada Based on Median dan Based on Median and with adjusted df nilai signifikannya sama yaitu 0,822 $(0,822>0,05)$, sedangkan pada Based on Trimmed Mean nilai signifikan sebesar 0,729 $(0,729>0,05)$. Dari data yang telah di uji homogenitas, maka $H_{\circ}$ diterima. Jadi dapat disimpulkan bahwa kedua varian sama (varian kelompok eksperimen 1 dan kelompok eksperimen 2).

Selanjutnya data hasil uji homogenitas posttest ketrampilan pemecahan masalah dan hasil belajar pada kelompok eksperimen 1 dan kelompok eksperimen 2 .

Tabel 4. Hasil Uji Homogenitas Posttest Ketrampilan Pemecahan Masalah dan Hasil Belajar pada Kelompok Eksperimen 1 dan eksperimen 2

Test of Homogeneity of Variance

\begin{tabular}{|c|c|c|c|c|c|}
\hline \multicolumn{6}{|c|}{ Levene } \\
\hline & & Statistic & df1 & df2 & Sig. \\
\hline \multirow[t]{4}{*}{ Data_posttest } & $\begin{array}{l}\text { Based on } \\
\text { Mean }\end{array}$ & ,031 & 1 & 115 & ,860 \\
\hline & $\begin{array}{l}\text { Based on } \\
\text { Median }\end{array}$ & ,026 & 1 & 115 & ,872 \\
\hline & $\begin{array}{l}\text { Based on } \\
\text { Median and } \\
\text { with adjusted } \\
\text { df }\end{array}$ & ,026 & 1 & 113,472 & ,872 \\
\hline & Based on & ,011 & 1 & 115 & ,915 \\
\hline
\end{tabular}


trimmed mean

Berdasarkan tabel 4 diatas dapat diketahui bahwa Test of Homogeneity of Variance pada Based on Mean menunjukan nilai signifikan sebesar 0,860 $(0,860>0,05)$, pada Based on Median dan Based on Median and with adjusted df nilai signifikannya sama yaitu 0,872 $(0,872>0,05)$, sedangkan pada Based on Trimmed Mean nilai signifikan sebesar 0,915 $(0,915>0,05)$. Dari data yang telah di uji homogenitas, maka $H_{\circ}$ diterima. Jadi dapat disimpulkan bahwa kedua varian sama (varian kelompok eksperimen 1 dan kelompok eksperimen 2).

Setelah menggunakan uji homogenitas varian data, selanjutnya akan dilakukan uji coba homogenitas koefisien regresi linear dimana semua kelompok eksperimen sebagai persyaratan analisis kovarian, antara variabel kovariat dengan variabel terikat berkolerasi cukup tinggi. pada kasus analisis kovariansi, koefisien korelasi 0.60 pada masing-masing kelompok sudah di anggap cukup memadai. Dalam penelitian eksperimen ini, variabel yang akan di uji sebagai prasyaratan analisis ANCOVA adalah koefisien korelasi antara pretest dan posttest kelompok eksperimen 1 (Discovery Learning) dan kelompok eksperimen 2 (Guided Discovery). Uji homoginetas koefisien regresi di lakukan dengan teknik analisis kofarian 1 jalan, dengan memperhatikan koefisien beta (B) pada tabel output parameter estimasi dan nilai t serta signifikansi / probabilitasnya. Syarat yang lain adalah bahwa nilai beta $(B)$ haruslah lebih besar sama dengan 0,60 . Jika probabilitasnya $<0,05$, maka koefisien regresi linier kedua sampel homogen.

Tabel 5. Hasil Uji Homogenitas Koefisien Regresi Linier Nilai Pretest-Postest Kelompok Eksperimen 1 dan Kelompok Eksperimen 2

Coefficientsa

\begin{tabular}{|c|c|c|c|c|c|c|}
\hline \multirow{3}{*}{\multicolumn{2}{|c|}{ Model }} & \multicolumn{2}{|c|}{$\begin{array}{l}\text { Unstandardized } \\
\text { Coefficients }\end{array}$} & $\begin{array}{l}\text { Standardized } \\
\text { Coefficients }\end{array}$ & \multirow{3}{*}{$\mathrm{t}$} & \multirow{3}{*}{ Sig. } \\
\hline & & & Std. & & & \\
\hline & & $\mathrm{B}$ & Error & Beta & & \\
\hline \multirow[t]{2}{*}{1} & (Constant) & 14,383 & 2,638 & & 5,452 &, 000 \\
\hline & pretest_modelpemb1 & ,961 & ,043 & ,950 & 22,098 & ,000 \\
\hline \multirow[t]{2}{*}{2} & (Constant) & 11,769 & 2,321 & & 5,071 & ,000 \\
\hline & pretest_modelpemb2 & ,968 & ,033 & ,966 & 29,093 &, 000 \\
\hline
\end{tabular}

Pada tabel 4.12 dapat dilihat nilai beta (B) Eksperimen 1 sebesar 0,961 dan nilai beta (B) Eksperimen 2 sebesar 0,968 lebih besar dari 0,60, nilai t Eksperimen 1 sebesar 22,098 dan nilai t Eksperimen 2 sebesar 29,093berada pada signifikan/probabilitas 0,000, maka koefisien regresi linier kedua sampel homogen dan model ANCOVAdapat digunakan.

Berdasarkan hasil uji normalitas yang menunjukkan data berdistribusi normal, uji homogenitas yang menunjukkan varian data homogen, dan uji homogenitas koefisien regresi linier yang menunjukkan kedua model beregresi linier maka dapat dikatakan uji persyaratan telah terpenuhi.uji analisis berikutnya adalah ANCOVA atau uji kombinasi analisis regresi dan varian.

ANCOVA (Analysis of Covariance) merupakan gabungan antara analisis regresi dan analisis varian (ANAVA). Setelah uji syarat analisis terpenuhi yakni data berdistribusi normal, 
data homogen, dan model regresi linier, maka uji analisis berikutnya adalah ANCOVA atau uji kombinasi analisis regresi dan varians. ANCOVA adalah analisis kovarian dengan memasukan kovariat kedalam model analisis. Pada analisis kovariansi, koefisien korelasi lebih dari 0.60 sudah dianggap cukup tinggi (Budiyono, 2011: 300).

Tabel 6. Hasil Uji ANCOVA TWO WAYS Nilai Pretest-Postest Kelompok Eksperimen 1 dan Kelompok Eksperimen 2

Test of Between-Subjects Effects

\begin{tabular}{lrrrrr}
\hline Source & $\begin{array}{c}\text { Type III Sum } \\
\text { of Squares }\end{array}$ & Df & Mean Square & F & Sig. \\
\hline Corrected Model & $7245.738^{\mathrm{a}}$ & 3 & 2.415 .246 & 8.402 & .000 \\
$\begin{array}{l}\text { Intercept } \\
\text { Skor_2 }\end{array}$ & 50258.648 & 1 & 50258.648 & 174.828 & .000 \\
hasil_belajar & 258.087 & 1 & 258.087 & .898 & .344 \\
ket.pemecahan & 7.771 & 1 & 7.771 & .027 & .870 \\
& 208.933 & 1 & 208.933 & .727 & .395 \\
hasil_belajar * & & & & & \\
ket.pemecahan & .000 & 0 & & & \\
Error & 66119.219 & 230 & 287.475 & & \\
Total & 1181100.000 & 234 & & & \\
Corrected Total & 73364.957 & 233 & & & \\
\hline
\end{tabular}

Ringkasan uji ANCOVA TWO WAYS seperti tertera dalam tabel 4.1 tersebut memberikan informasi besarnya nilai $\mathrm{F}$ dan sigifikansinya. Pada sumber varian corrected model, nampak bahwa $\mathrm{F}$ hitung sebesar 8,402 dengan taraf signifikansi hitung 0,000. Oleh karena $0,000<\alpha=0,050$, maka dampak variabel independen secara simultan terhadap variabel dependen signifikan. Maknanya bahwa model pembelajaran Discovery Learning dan pretest secara simultan memiliki dampak yang berbeda secara signifikan terhadap hasil belajar siswa, dibandingkan dengan model pembelajaran Guided Discovery Pada varian intercept nampak bahwa $F$ hitung sebesar 174,828 dengan taraf signifikansi hitung 0,000. Oleh karena $0,000<\alpha=0,050$, maka nilai intercept signifikan. Nilai intercept merupakan besaran konstanta perubahan nilai variabel dependen sebesar nilai tersebut meskipun tanpa dipengaruhi keberadaan kovariat dan variabel independen. Pada kovarian skor_2 diperoleh data $F$ hitung 0,898 , dengan taraf signifikansi 0,344 . Oleh karena $0,344>\alpha=0,050$, maka nilai dampak kovariat tidak signifikan. Artinya tidak ada perbedaan antara ketrampilan pemecahan masalah menggunakan model Discovery Learning dan Guided Discovery yang berdampak pada hasil belajar matematika.

\section{Simpulan Dan Saran}

Berdasarkan hasil penelitian dapat disimpulkan bahwa tidak terdapat perbedaan hasil belajar matematika yang signifikan pada siswa kelas 4 SD Dabin 2 dan Dabin 3 dalam menggunakan model pembelajaran Discovery Learning dan Guided Discovery. Hal ini 
didasarkan pada hasil uji hipotesis 0,870 dan 0,395 atau > 0,05 maka $\mathrm{HO}$ diterima dan $\mathrm{Ha}$ ditolak. Artinya tidak terdapat perbedaan ketrampilan pemecahan masalah dan hasil belajar matematika yang signifikan pada siswa kelas 4 SD Dabin 2 dan Dabin 3 dalam pembelajaran menggunakan model pembelajaran Discovery Learningdan Guided Discovery.

Signifikansi perlakukan dimana tidak terdapat perbedaan hasil belajar matematika yang signifikan pada siswa kelas 4 SD Dabin 2 dan 3 dalam pembelajaran menggunakan model pembelajaran Discovery Learning dan Guided Discovery didukung oleh rerata dari dua sampel dimana rerata ketrampilan pemecahan masalah dan hasil belajar pada penerapan model pembelajaran Discovery Learning sebesar 70,54, dan rerata hasil belajar pada penerapan model pembelajaran Guided Discovery sebesar 77,42. Maknanya adalah bahwa tidak ada perbedaan rerata hasil belajar yang signifikansi dalam membuktikan bahwa model pembelajaran Discovery Learning dan Guided Discovery sama-sama memberikan dampak lebih tinggi terhadap ketrampilan pemecahan masalah dan hasil belajar.

Guru harus memperhatikan model pembelajaran yang cocok pada saat pembelajaran berlangsung terutama pada mata pelajaran matematika dalam meningkatkan ketrampilan pemecahan masalah dan hasil belajar.

\section{Daftar Rujukan}

Depdiknas. (2006:49). Pendidikan Kewarganegaraan. Jakarta

Depdiknas. (2014). Model Discovery Learning. Jakarta

Kemendikbud. (2014). Mengembangkan Aspek Konsep Keterampilan dan Emosi Secara Keseluruhan Kurang Mendapat Perhatian. Jakarta

Departemen Pendidikan Nasional, 2003. Undang-Undang Nomor 20 Tahun 2003, Tentang Sistem Pendidikan Nasional. Jakarta: Depdiknas.

Giarti, Sri. 2014. Peningkatan Ketrampilan Proses Pemecahan Masalah dan Hasil Belajar Matematika Menggunakan Model PBL Terintegrasi Penilaian Autentik Pada Siswa Kelas VI SD N 2 Bengle, Wonosegoro. Scholaria, Vol 4 (3) 13-27.

Muhsetyo Gatot, dkk. 2009. Pembelajaran Matematika SD. Jakarta: Universitas Terbuka.

Depdiknas.2007. Peraturan Menteri Pendidikan Nasional RI Nomor 41 Tahun 2007 Tentang Standar Proses untuk Satuan Pendidikan

Astuti, M. S. (t.thn.). Peningkatan Ketrmapilan Bertanya dan Hasil Belajar Siswa Kelas 2 SD N Slungkep 03 Menggunakan Model Discovery Learning. Scholaria .

Firosalia, K., \& Dwi, R. (2015). Pengaruh Penerapan Model Pembelajaran Discovery Learning Terhadap Hasil Belajar IPS Pada Siswa Kelas 4 SD. Scholaria , 25-26.

Hujair. (2013). Media Pembelajaran Interaktif-Inovatif. Yogyakarta: Kuka Dipantara. 
Meiria, S. A. (2014). Peningkatan Keterampilan Bertanya dan Hasil Belajar Siswa Kelas 2 SDN Slungkep 03 Menggunakan Model Discovery Learning. Scholaria , 7.

Rumini, \& Naniek, S. W. (2015). Upaya Peningkatan Hasil Belajar Tema Berbagai Pekerjaan Melalui Model Discovery Learning Siswa Kelas 4 SD N Kutoharjo 01 Pati Kabupaten Pati Semester 1. Scholaria, 20.

Slameto. (2015). Metode Penelitian dan Inovasi Pendidikan . Salatiga: Satya Wacana Univercity Press.

Uno,H. 2007. Model Pembelajaran Menciptakan Proses Belajar Mengajar Yang Kreatif Dan Efektif. Jakarta: Bumi Aksara.

Ibrahim dan Suparni. 2012. Pembelajaran Matematika Teori dan Aplikasinya. Yogyakarta: UKA-press UIN Sunan Kalijaga.

Affandi Muhammad, dkk. 2013. Model dan Metode Pembelajaran di Sekolah. Semarang: Sultan Agung Press

Djamarah, S. B. (2008). Strategi belajar Mengajar. Bandung: Rineka Cipta.

Sugiyono. 2006. “Metode Penelitian Kuantitatif Kualitatif dan R\&D”. Bandung: Alfabeta.

Sugiyono. 2009. Metode Penelitian Bisnis (Pendekatan Kuantitatif, Kualitatif, dan R\&D). Bandung: Alfabeta.

Sugiyono. 2015. Metode Penelitian Pendidikan (Pendekatan Kuantitatif, Kualitatif dan R\&D). Penerbit CV. Alfabeta: Bandung.

Arikunto, Suharsimi. 2009. Dasar-dasar Evaluasi Pendidikan. Aneka Cipta: Jakarta

Sugiyono.(2013). Metode Penelitian Pendidikan Pendekatan Kuantitatif, Kualitatif, dan R\&D. Bandung: ALFABETA.

Azwar, S., 2011. Sikap dan Perilaku. Dalam: Sikap Manusia Teori dan Pengukurannya. 2nd ed. Yogyakarta: Pustaka Pelajar, 3-22. 